\title{
PENGARUH JARAK ALUR TERHADAP KESTABILAN ALIRAN \\ FLUIDA BERDENYUT DALAM SALURAN BERPENAMPANG SEGIEMPAT
}

\author{
Prayitno Ciptoadi \\ E-mail: pcipto@gmail.com \\ Program studi Teknik Sistem Perkapalan, Fakultas Teknik Universitas Pattimura
}

\begin{abstract}
The pulsatile fluid flow in a transverse grooved channel would becomes self-sustained oscillatory flow at certain critical Reynold number. The critical Reynold number where laminar unsteady flow changed to unsteady transitional one depends on grooves distances. The objective of this research is to analyze the effect of grooves distances toward the vortex strenght and the stability of the fluid flow. This research was done by implementing a closed square cross section channel, where the bottom surface of the channel was semicircle grooved. The frequency of flow oscillation measurement was done by setting up a resistance manometer and measurement was done at severals Reynold number. From the research result it is seen that the largest vortex strength occurs at the smallest groove distance. The flows become instability in all of grooves distances by seen Phase Plane method .
\end{abstract}

Key word: Pulsatile flow, grooved channel, vortex strength, stability.

\section{PENDAHULUAN}

Pada aliran laminar di dalam saluran beralur melintang terdapat dua daerah aliran: (i) aliran utama dalam saluran dan (ii) aliran vortex resirkulasi dalam alur. Dua daerah tersebut dipisahkan oleh lapisan geser bebas (free shear layer). Dalam kondisi stedi, tidak ada pertukaran fluida antara kedua daerah ini. Salah satu kemungkinan untuk meningkatkan laju transport dalam saluran beralur adalah memperbaiki pencampuran lateral (lateral mixing) dengan mengganggu lapisan geser pemisah antara aliran utama dan aliran resirkulasi dalam alur (Kang, 2001). Gerakan aliran utama dari hulu ke hilir mengalami defleksi ke dalam alur pada Re 50 sementara aliran vortex di dalam alur bergerak ke hilir seiring meningkatnya $\operatorname{Re}$ (Adachi dan Uehara, 2003).

Gangguan lapisan geser pemisah yang terjadi seiring meningkatnya bilangan Re akan mengubah kondisi aliran dari stedi ke aliran osilasi pada bilangan Re yang lebih kecil dibandingkan jika fluida mengalir dalam saluran tanpa alur. Aliran osilasi ini dikenal sebagai aliran yang berosilasi terus-menerus (self-sustained oscillatory flow). Bilangan Reynold kritis di mana permulaan selfsustained oscillatory flow terjadi tergantung pada panjang alur yakni menjadi lebih kecil jika panjang alur meningkat (Nishimura et al., 2001).

Osilasi aliran terjadi akibat aliran stedi menjadi tidak stabil karena mengalami bifurkasi pada bilangan Reynold kritis tertentu. Ketidakstabilan ini muncul karena dipicu oleh munculnya Tollmien-Schlichting wave. Aliran yang berosilasi menginduksi tegangan Reynold (Reynold stress) dan mampu meningkatkan difusi momentum yaitu mengangkut energi dari aliran utama ke aliran osilasi dan mempertahankannya. Akibatnya rugi tekanan (pressure drop) dari aliran utama meningkat. Ketidakstabilan KelvinHelmholtz terbentuk pada tepi alur disebabkan oleh formasi pelengkungan lintasan profil kecepatan, menekan gelombang TollmienSchlichting di bagian luar alur dan memproyeksikan energi padanya. Akibat dari interaksi kompleks, menghasilkan gelombang berjalan dua dimensi (two-dimensional traveling waves) pada bilangan Re cukup rendah (Adachi dan Uehara, 2003).

Kekuatan vortex dihubungkan dengan pertukaran fluida antara alur dan saluran dan transport momentum osilasi melintasi shear layer (Nishimura et al., 2001). Pada aliran fluida berdenyut di dalam saluran beralur melintang, 
vortex utama muncul dalam alur pada dinding bagian bawah saluran selama fasa deselerasi (deceralation phase) dan suatu vortex tambahan dibangkitkan dekat dinding rata pada bagian atas saluran. Proses pengisian dan pengosongan vortex utama menimbulkan pertukaran fluida antara alur dan saluran (Nishimura et al., 1997).

Aliran laminar dalam saluran beralur yang bertujuan untuk meningkatkan laju transport banyak dijumpai. Dalam bidang teknik seperti alat penukar kalor (compact heat exchanger), sistem pendingin mikroelektronik (Adachi dan Uehara, 2003) dan juga dalam bidang kedokteran serta biokimia (Nishimura et al.,1997). Banyak penelitian telah dilakukan untuk mengetahui perilaku aliran fluida dalam saluran beralur melintang. Penelitian-penelitian tersebut dilakukan pada berbagai kondisi aliran baik kontinyu maupun berdenyut dan berbagai bentuk alur seperti segiempat, segitiga atau setengah lingkaran namun jarak alur tetap. Oleh karena itu penelitian ini memberikan data perilaku aliran fluida berdenyut dalam saluran beralur melintang dengan jarak alur yang berubah-ubah.

\section{KAJIAN TEORI DAN METODE}

\section{KAJIAN TEORI}

Karakteristik osilasi aliran ditentukan oleh bilangan Strouhal Str dengan persamaan (White, 1991):

$$
\text { Str }=\frac{f h}{U}
$$

dengan $f=$ frekuensi osilasi aliran, $\mathrm{Hz}$

Gerakan fluida diatur oleh persamaan Navier Stokes yang ditulis dalam notasi vektor sebagai berikut (White, 1991: 69)

$$
\begin{aligned}
& \rho\left[\frac{\partial U}{\partial t}+(U \cdot \nabla) U\right]= \\
& -\nabla p+\rho g+\mu \nabla^{2} U
\end{aligned}
$$

dengan:

$$
\begin{aligned}
\mu & =\text { viskositas dinamik, N.det. } \mathrm{m}^{-2} \\
U & =\text { kecepatan fluida, } \mathrm{m} \cdot \mathrm{det}^{-1} \\
t & =\text { waktu, det }
\end{aligned}
$$

Didefenisikan vorticity vector $\Omega$, suatu ukuran dari efek rotasi lokal elemen fluida (White, 1991: 89)

$$
\Omega=\operatorname{curl} U=2 x \omega
$$

Jika diambil curl dari persamaam (3) diperoleh persamaan transport vorticity (Raisinghania, 2002: 639)

METODE $(\Omega \cdot \nabla) U+v \nabla^{2} \Omega$

\section{PENELITIAN}

Penelitian dilakukan dengan menggunakan peralatan seperti pada gambar 1 .

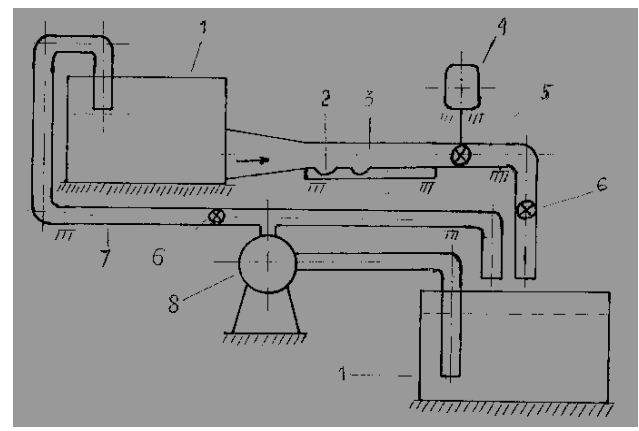

Gambar 1. Instalasi Penelitian

Kerangan:

1. Tandon air

2. Alur setengah lingkaran

3. Saluran

4. Motor listrik

5. Katup denyut

6. Katup pengatur aliran

7. Pipa-pipa

8. Pompa

Saluran dibuat dari bahan tembus pandang (mika) berpenampang segiempat. Ukuran saluran adalah panjang $1=450 \mathrm{~mm}$, lebar $\mathrm{W}=120 \mathrm{~mm}$, tinggi $\mathrm{h}=14 \mathrm{~mm}$. Bagian atas saluran dibuat rata sedangkan bagian bawah diberi alur (groove). Alur dibuat berbentuk setengah lingkaran dengan ukuran jari-jari $\mathrm{r}=11,5 \mathrm{~mm}$. Jumlah alur yang digunakan dua buah dengan jarak antar alur $\mathrm{L}$ dibuat periodik terhadap keliling alur $\mathrm{K}$ yaitu $1 / 2$ $\mathrm{K}(\mathrm{G} 1), \quad 3 / 4 \mathrm{~K}(\mathrm{G} 2)$ dan $\mathrm{K}(\mathrm{G} 3)$ dengan $\mathrm{K}=72,22$ $\mathrm{mm}$. Agar aliran dapat berdenyut, sebuah katup denyut yang digerakan oleh motor listrik dengan kecepatan putar 66 rpm ditempatkan pada bagian hilir saluran. Sebagai pembanding digunakan 
juga saluran tanpa alur (G0). Fluida kerja yang digunakan adalah air, kondisi aliran laminar dua dimensi. Variabel penelitian meliputi variabel bebas yaitu: Bilangan Reynold Re dan Jarak antar alur L sedangkan variabel terikat yaitu: frekuensi osilasi aliran.

\section{Teknik Pengambilan data}

\section{Pengukuran Debit Aliran}

Pengukuran debit aliran Q, berdasarkan volume air yang mengalir per satuan waktu. Volume air yang mengalir diatur melalui pembukaan katup yang ditempatkan sebelum dan sesudah saluran beralur. Data debit aliran digunakan untuk menentukan kecepatan aliran fluida dan bilangan Reynold. Kecepatan aliran fluida $=$ debit aliran dibagi luas penampang saluran $(\mathrm{U}=\mathrm{Q} / \mathrm{A})$ sedangkan bilangan Reynold Re dihitung dengan menggunakan persamaan (Nishimura et al., 2001):

$$
\operatorname{Re}=\frac{U h}{v}
$$

dengan $U=$ laju aliran, m.det ${ }^{-1}$

$h=$ tinggi saluran, $\mathrm{m}$

$\mathrm{v}=$ viskositas kinematik

$$
\left(1,007 \times 10^{-6}, \mathrm{~m}^{2} \operatorname{det}^{-1}\right)
$$

Hasil perhitungan kecepatan aliran dan Re dapat dilihat pada Tabel 1.

Tabel 1. Hasil Perhitungan Kecepatan

\begin{tabular}{|c|c|c|c|}
\hline $\begin{array}{l}\mathrm{N} \\
\mathrm{O}\end{array}$ & $\operatorname{Re}$ & $\mathrm{Q}, \mathrm{m}_{1}^{3} \mathrm{det}^{-}$ & $\mathrm{U}, \underset{1}{\operatorname{mdet}}$ \\
\hline 1 & 200 & $2,42 \times 10^{-}$ & 0,0144 \\
\hline 2 & 450 & 5 & 0,032 \\
\hline 3 & 700 & $5,44 \times 10^{-}$ & 0,050 \\
\hline 4 & 950 & & 0,068 \\
\hline 5 & 1200 & $8,46 \underset{5}{x} 10^{-}$ & 0,086 \\
\hline & & $1,15 \underset{4}{x} 10^{-}$ & \\
\hline & & $1,45 \underset{4}{x} 10^{-}$ & \\
\hline
\end{tabular}
Aliran dan Re

Sumber: Hasil pengukuran (data diolah)

\section{Pengambilan Data Fluktuasi Kecepatan Aliran \\ Pengambilan data seperti terlihat pada gambar 2. Data diambil menggunakan sensor tegangan (salah satu tahanan jembatan}

Wheatstone) yang ditempatkan di dalam manometer yang berisi air.

Manometer dihubungkan dengan saluran sedangkan sensor dihubungkan dengan ADC. Data ini ditampilkan pada monitor komputer dalam bentuk grafik dan teks kemudian disimpan dalam bentuk teks. Untuk menjamin keakuratan, jumlah data yang diambil adalah 400 data per detik dan dilakukan 5 kali pengulangan untuk tiap perlakuan. Pengambilan data ini diulangi untuk beberapa nilai variabel bebas.

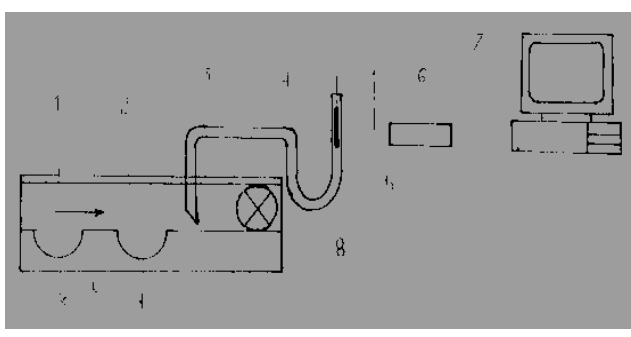

Gambar 2. Pengukuran Fluktuasi Kecepatan Aliran Fluida

Keterangan:

1. Saluran

2. Alur setengah lingkaran

3. Pipa plastik

4. Manometer

5. Sensor tegangan

6. ADC

7. PPI card dan komputer

8. Katup denyut

L: Jarak antar alur

\section{HASIL DAN PEMBAHASAN}

Data fluktuasi kecepatan diolah dengan menggunakan program FFT untuk memperoleh frekuensi-frekuensi yang dominan dari tiap-tiap perlakuan. Selanjutnya dari data-data tersebut dihitung bilangan Strouhal Str.

\section{Kekuatan Vortex}

Kekuatan vortex digambarkan dengan bilangan Strouhal Str dan Energi Kinetik yang dikandung oleh vortex.

\section{Grafik Kekuatan Vortex vs Bilangan Str}

Pada aliran fluida laminar dalam saluran beralur akan terbentuk shear layer antara aliran utama dalam saluran dan aliran resirkulasi dalam alur. Untuk aliran yang berdenyut, pada fase akselerasi (katup denyut mulai membuka) shear 
layer mulai mengalami separasi. Sebuah vortex utama terbentuk dalam alur pada tepi atas sisi hulu. Pada saat laju aliran utama maksimum (katup denyut terbuka penuh) vortex utama memenuhi seluruh bagian alur. Ketika fase deselerasi (katup denyut mulai tertutup) vortex utama berkembang hingga keluar dari tepi alur. Disamping itu terbentuk vortex tambahan pada saluran rata dekat dinding bagian atas dengan tanda yang berlawanan dengan vortex utama. Kedua vortex yang berpasangan (vortices) tersebut memenuhi keseluruhan saluran pada saat laju aliran utama minimum (katup denyut tertutup). Setelah itu vortex tambahan menghilang. Proses ini berlangsung terus mengikuti osilasi aliran utama (Nishimura et al., 1997).

Dari fenomena di atas dapat dilihat bahwa terjadi penggabungan vortex (merging) ketika laju aliran utama minimum. Proses ini didominasi oleh efek tak stedi $(\partial \Omega / \mathrm{jt})$ dan efek kekentalan $\left(v \mathrm{~V}^{2} \Omega\right)$ dari persamaan (4) sedangkan efek inersia non linear $(\mathrm{U} \cdot \mathrm{V}) \Omega$ berkurang. Pertumbuhan vortex utama di dalam alur selama fase deselerasi menimbulkan semprotan (ejection) fluida di dalam alur dan menghasilkan pertukaran partikelpartikel fluida antara alur dan saluran melintasi shear layer (Nishimura et al., 2001). Interaksi antara vortex utama di dalam alur dan vortex tambahan di dalam saluran juga meningkatkan pencampuran (mixing) fluida yang didominasi oleh efek vortex-stretching $(\Omega \cdot \mathrm{V}) \mathrm{U}$ dari persamaan (4) (Gloerfelt et al., 2002).

Pertukaran partikel-pertikel fluida antara alur dan saluran dihubungkan dengan kekuatan vortex utama dan transport momentum osilasi melintasi shear layer tergantung pada bilangan $\mathrm{Re}$ dan bilangan Str. Hubungan antara kekuatan vortex dan bilangan $\mathrm{Re}$ untuk tiap perlakuan pada bilangan Re tertentu dapat dilihat pada gambar 3 .

Dari grafik pada gambar 3 terlihat bahwa kekuatan vortex meningkat seiring meningkatnya bilangan Str. Kekuatan vortex mencapai nilai maksimum pada bilangan Str tertentu disebabkan pada nilai bilangan Str tersebut telah terjadi self sustained oscillatory flow. Kondisi ini dikarenakan oleh kecepatan aliran osilasi di dalam alur telah mencapai kecepatan aliran utama di dalam saluran dimana terjadi peningkatan amplitudo vortex utama dan munculnya vortex tambahan. Dari grafik juga dapat dilihat bahwa nilai bilangan Str pada mana kekuatan vortex maksimum untuk $\mathrm{G} 1<\mathrm{G} 2<\mathrm{G} 3$. Hal ini mengindikasikan bahwa interaksi antara vortexvortex utama dalam dua alur dipengaruhi oleh jarak antar alur. Interaksi akan lebih kuat dan lebih cepat mencapai nilai maksimum pada jarak antar alur paling pendek. Untuk saluran tanpa alur kekuatan vortex hanya tergantung pada osilasi aliran utama dan nilainya kecil dibandingkan dengan nilai kekuatan vortex pada saluran beralur.

Grafik bilangan Str vs kekuatan vortex diverifikasi dengan penelitian Nishimura et. al, (2001) pada bilangan Re 200. Kekuatan vortex maksimum dari Nishimura et. al, (2001) lebih tinggi karena faktor geometri alur. Pada penelitian mereka digunakan alur berbentuk segiempat dengan panjang alur dua kali kedalamannya.
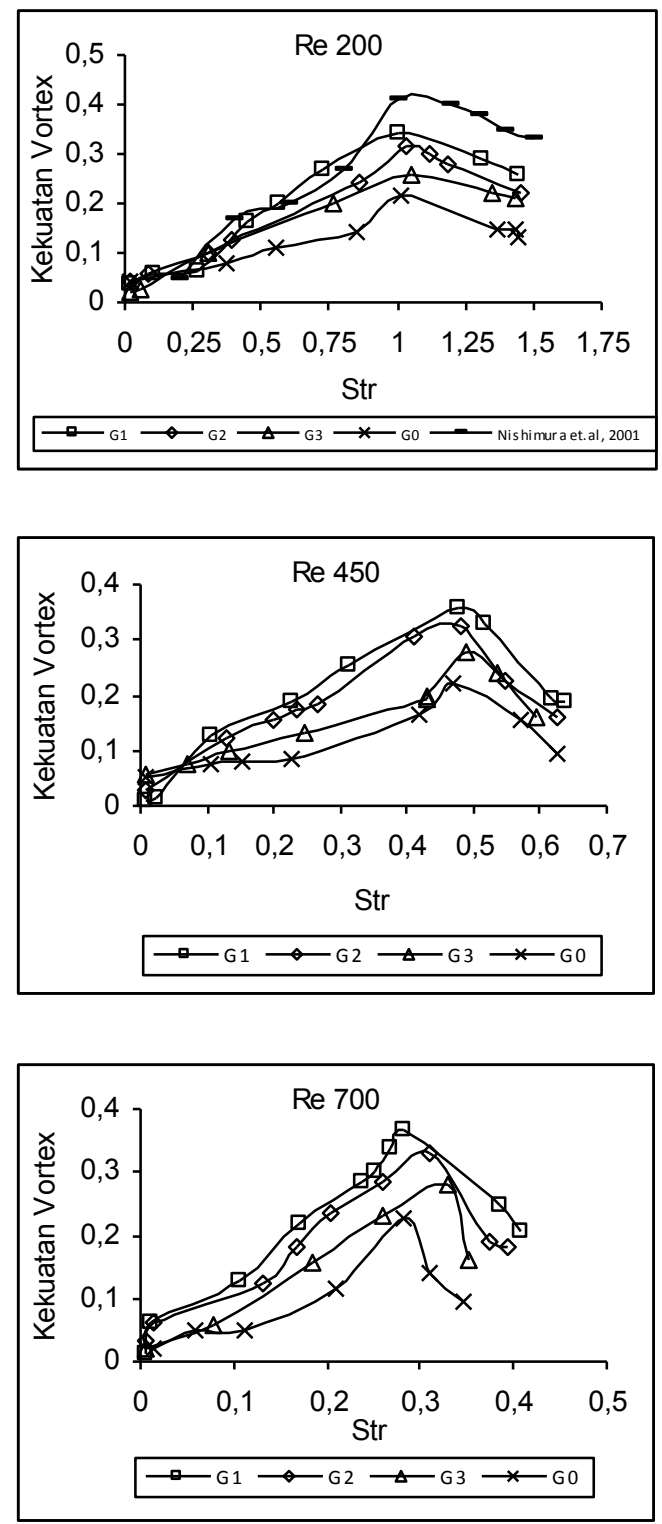


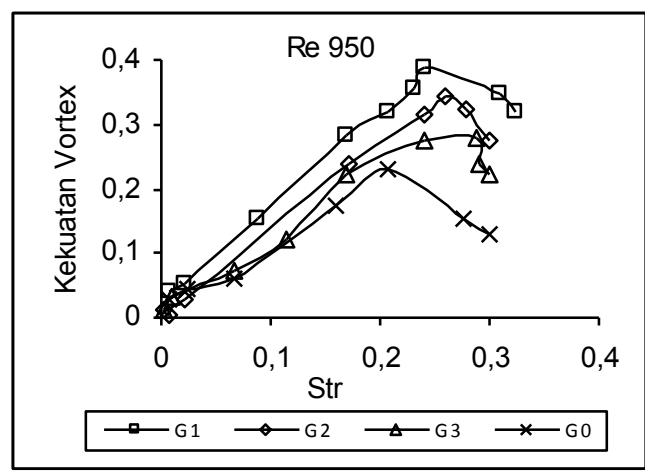

Gambar 3. Grafik Kekuatan Vortex vs Str

\section{Kestabilan Aliran Fluida}

Kestabilan adalah kemampuan suatu sistem dinamik untuk kembali ke kondisi keseimbangan awal setelah dikenai suatu gangguan. Dari hasil pengukuran fluktuasi kecepatan aliran fluida dan hasil perhitungan frekuensi aliran fluida ternyata aliran fluida mengalami ketidakstabilan karena mendapat gangguan baik dengan adanya alur dalam saluran maupun dengan adanya katup denyut. Ketidakstabilan aliran fluida seperti terlihat pada Grafik Bidang Fasa aliran pada Gambar 4.

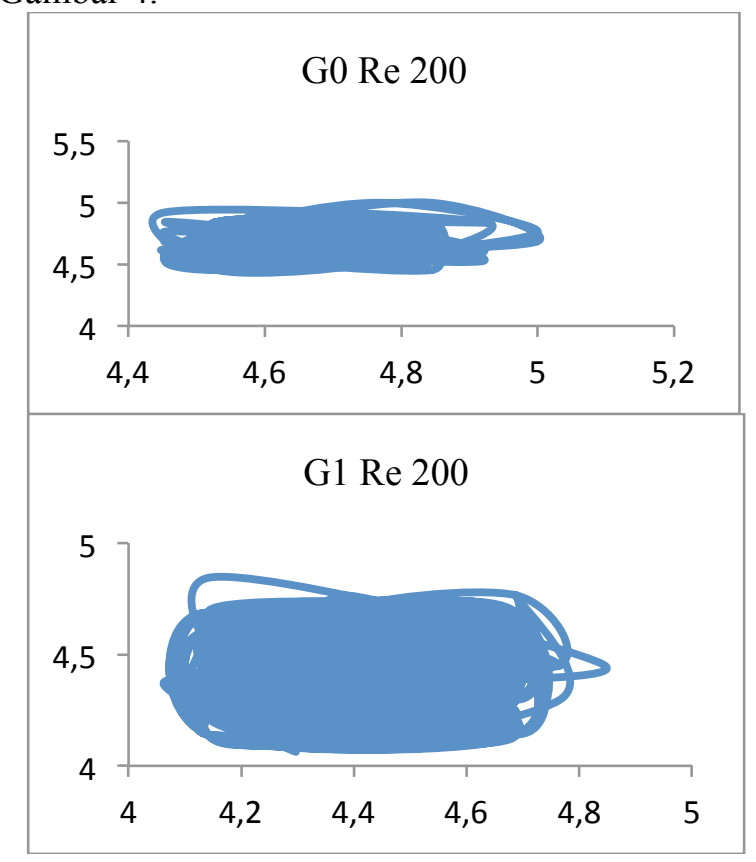

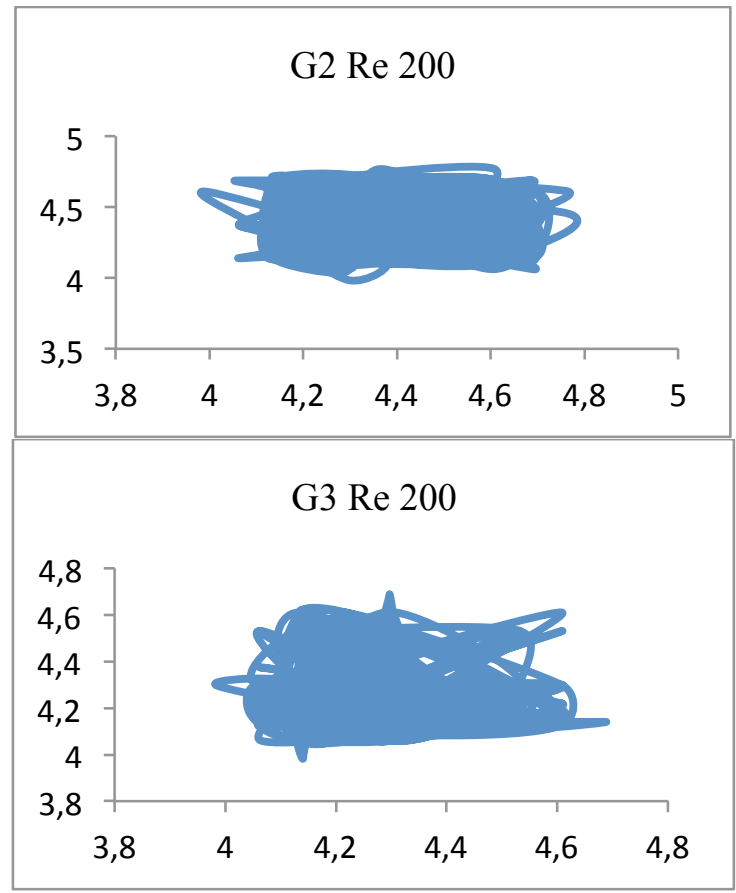

Gambar 4. Grafik Bidang Fasa

\section{KESIMPULAN}

Berdasarkan hasil dan pembahasan disimpulkan hal-hal sebagai berikut:

1. Kekuatan vortex dipengaruhi oleh bilangan Re, bilangan Str dan jarak antar alur. Pada interval bilangan $\mathrm{Re}$ laminar tak stedi bilangan Str untuk G1, G2, G3 dan G0 mempunyai nilai yang identik sedangkan pada interval bilangan Re transisi tak stedi bilangan Str untuk G1 bernilai paling tinggi diikuti oleh G2, G3 dan G0.

2. Aliran fluida periodik dalam saluran yang beralur melintang mengalami ketidakstabilan meskipun pada bilangan Re yang rendah.

\section{DAFTAR PUSTAKA}

Adhaci, T. and Uehara, H. 2003. Linear Stability Analisys of Flow in a Periodically Grooved Channel, International Journal for Numerical Methods in Fluids (41): 601-613.

Ciptoadi, P. 2006. Pengaruh Jarak Alur Terhadap

Kekuatan Vortex dan Rugi Tekanan Aliran

Fluida Berdenyut Dalam Saluran

Berpenampang Segiempat, Journal IlmuIlmu Teknik Diagonal, Fakultas Teknik Universitas Merdeka Malang, Vol, 7 No. 1

Ciptoadi, P. 2009. Pengaruh Jarak Alur Terhadap Kekuatan Vortex dan Tegangan Geser Osilasi Aliran Fluida Berdenyut Dalam Saluran Berpenampang Segiempat, Jurnal 
Teknologi, Fakultas Teknik Universitas Pattimura, Vol, 6 No. 2

Ciptoadi, P. 2011. Pengaruh Jarak Alur Terhadap Kekuatan Vortex dan Bilangan Reynold Kritis Aliran Fluida Berdenyut Dalam Saluran Berpenampang Segiempat, Jurnal Teknologi, Fakultas Teknik Universitas Pattimura, Vol, 8 No. 1

Gloerfelt, X.; Bogey, Ch.; Bailly, Ch. and Juve, D. 2002. Aerodynamic Noise Induced by Laminar and Turbulent Boundary Layer Over Rectangular Cavities, American Institute of Aeronautics and Astronautics, 2476

Kunitsugu, T. and Nishimura, T. 2000. The Development Process of Self-Sustained Oscillatory Flow in a Grooved Chanel, Department of Mechanical Engineering, Yamaguchi University, Ube, 755- 8611 Japan.

Nishimura, T.; Morega, A.M. and Kunitsugu, K, 1997. Vortex Structure and Fluid Mixing in Pulsatile Flow Through Periodically Grooved Channels at Low Reynold Numbers, JSME International Journal Series B, Vol. 40, No. 3: 377-385.

Nishimura, T.; Yoshinaka, M, and Kunitsugu, K. 2001. Oscillatory Momentum Transport and Fluid Mixing in Grooved Channels for Pulsatile Flow, Department of Mechanical Engineering, Yamaguchi University, Ube, 755-8611 Japan.

Raishingania, M.D. 2002. Fluid Dynamics (With Hydrodynamics) Fourth revised edition, S. Chand \& Company LTD. New Delhi.
White, F.M. 1991. Viscous Fluid Flow, Second edition, McGraw-Hill, Inc. 